\title{
Residual iliofemoral thrombosis in a 31-year-old woman on oral contraceptives possessing heterozygous factor V Leiden, factor XIII Val34Leu allele and $\alpha$-fibrinogen Thr312Ala allele
}

\author{
Mariola Cieśla-Dul1,2, Bogusław Gawęda ${ }^{1,2}$, Ewa Wypasek², Maria Różańska³ , Jerzy Sadowski1,2 \\ 1 Department of Cardiovascular Surgery and Transplantology, Institute of Cardiology, Jagiellonian University School of Medicine, Kraków, Poland \\ 2 John Paul II Hospital, Kraków, Poland \\ 3 5th Military Hospital with Polyclinic, Kraków, Poland
}

\section{KEY WORDS}

fibrin, iliofemoral thrombosis, thrombophilia
Correspondence to:

Mariola Cieśla-Dul, MD, PhD, Klinika Chirurgii Serca, Naczyń i Transplantologii, Instytut Kardiologii, Uniwersyte Jagielloński, Collegium Medicum, ul. Prądnicka 80, 31-022 Kraków, Poland, phone: +48-12-614-30-75, fax: +48-12-423-39-00, e-mail: mdul@szpitaljp2.krakow.pl Received: September 13, 2009. Revision accepted: November 20, 2009 Conflict of interest: none declared. Pol Arch Med Wewn. 2009; 119 (12): 822-825

Copyright by Medycyna Praktyczna, Kraków 2009

\section{ABSTRACT}

We present the case of a 31-year-old woman on oral contraceptives with a 3-year history of iliofemoral thrombosis resistant to recanalization despite satisfactory anticoagulation therapy and absence of concomitant diseases. Thrombophilia screening revealed heterozygous factor $V$ Leiden mutation. We also detected the presence of factor XIII (FXIII) Leu34 allele and a-chain fibrinogen 312Ala allele, which are known to adversely affect fibrin clot structure and lysis. It might be speculated that the presence of 3 polymorphisms in this patient could contribute to proximal thrombosis resistant to treatment. We postulate that determination of FXIII and a-fibrinogen polymorphisms can be useful in the evaluation of some young patients with deep vein thrombosis.

INTRODUCTION Iliofemoral deep vein thrombosis (DVT) occurs in about $20 \%$ of patients with DVT. ${ }^{1}$ This form of proximal DVT requires prompt anticoagulant treatment to prevent pulmonary embolism and/or chronic venous insufficiency (CVI).

DVT can be caused by inherited or acquired hemostatic disorders predisposing to thrombus formation, i.e., thrombophilia. The most frequent cause of thrombophilia is factor Va resistance to activated protein $C$ due to the factor $V$ (FV) G1691A (Leiden) mutation. FV Leiden is detected in $5 \%$ of the general population in Poland. The risk of thrombosis is markedly increased in carriers of this mutation receiving estrogens.

However, the cause of DVT cannot be determined in about $30 \%$ to $50 \%$ of patients despite screening for the presence of hypercoagulability, which implies that not all genetic and acquired factors predisposing to thrombosis have been identified. This is especially important in young patients with proximal DVT.

We describe the case of a young woman with iliofemoral DVT and a 3-year history of unsuccessful recanalization, in whom genetic polymorphisms favoring the formation of compact fibrin resistant to lysis have been detected.

CASE REPORT A 31-year-old woman (weight $56 \mathrm{~kg}$, height $171 \mathrm{~cm}$, body mass index $19 \mathrm{~kg} / \mathrm{m}^{2}$ ) was referred to the outpatient clinic for evaluation of persistent swelling of the left lower extremity.

In 2004, the patient with no family history of venous thromboembolism (VTE) was diagnosed as having DVT involving the left lower limb with lumen occlusions in the common femoral vein and the left external iliac vein. For about 3 months prior to the signs and symptoms, the patient had been on a contraceptive, Yasminelle ( $0.02 \mathrm{mg}$ ethinyl estradiol + 3 mg drospirenone, Schering, Poland). She had 2 normal pregnancies giving birth to babies at the age of 25 and 29 years, and a year later a spontaneous abortion at 12 weeks gestational age of unknown cause. Following confirmation of the diagnosis by means of ultrasound examination, the patient was advised to discontinue oral contraception and received anticoagulation 
FIGURE 1 Ultrasound examination of the affected veins of the left inferior extremity

A left external iliac vein (arrow) on admission B left common femoral vein (arrow) on admission C left common femoral vein (arrow indicates residual thrombosis)

D left external iliac vein (arrow)

E left common femoral vein after 9 additional months of therapy with enoxaparin

F vulval veins (arrows)
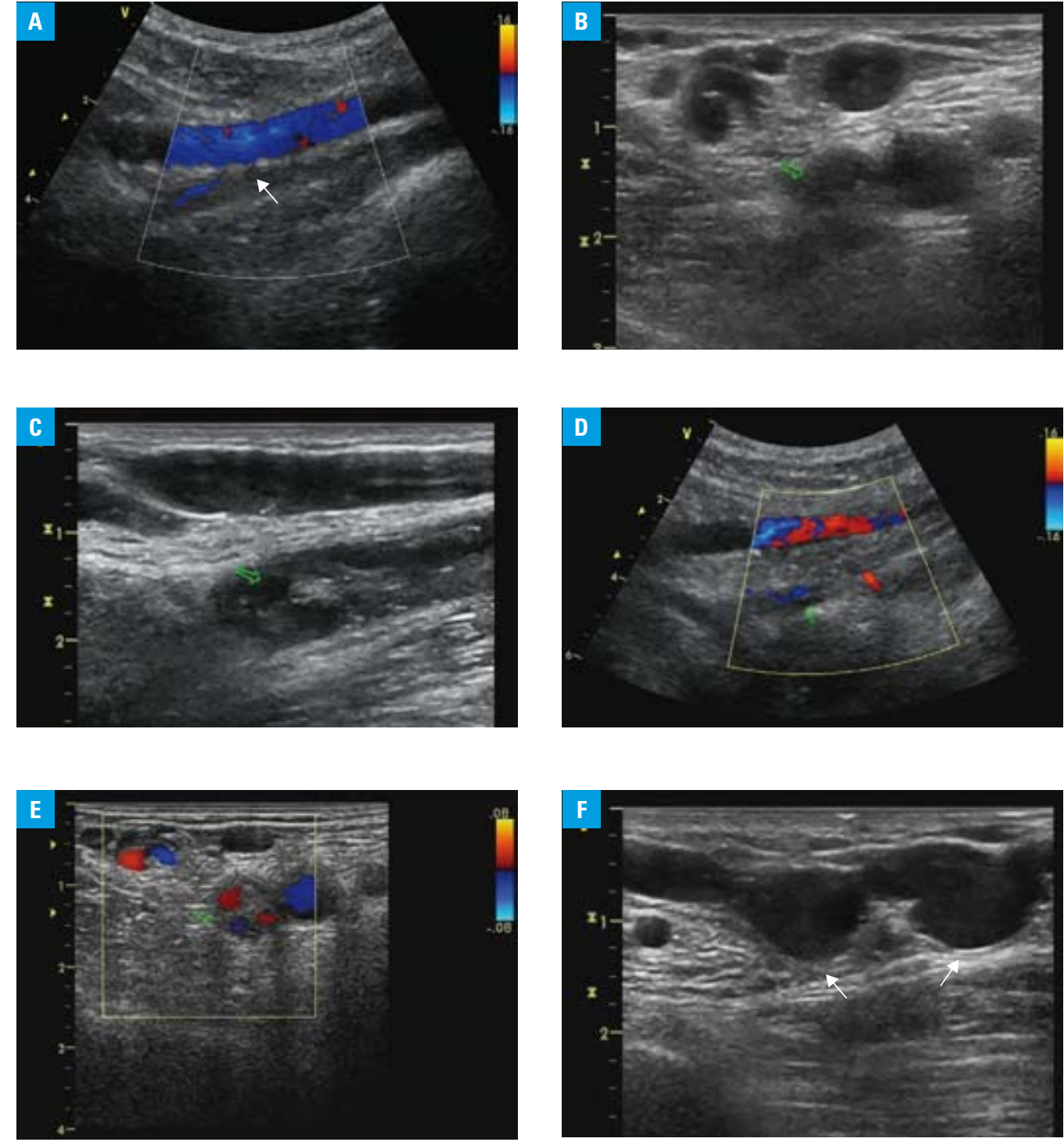

with enoxaparin for 10 days followed by acenocoumarol to achieve an international normalized ratio (INR) of 2.5 to 3.0 for about 3 years.

Physical examination on admission revealed swelling of the left leg (the circumference of the left thigh was $3 \mathrm{~cm}$ longer than the right) and suprapubic varicose veins in the region of the left inferior epigastric vein. Basic laboratory results and a plasma $\mathrm{D}$-dimer concentration were normal. There were no signs suggestive of a neoplasm, and tumor markers for breast, ovarian, and gastric cancers were negative (CA-125, CA19-9, carcinoembryonic antigen, $\alpha$-fetoprotein, breast cancer [BRCA 1, BRCA 2]). The patient had 3 points using the Wells score (edema - 1 point, asymmetry $>3 \mathrm{~cm}-1$ point, venous collaterals -1 point), which measures clinical probability of DVT. Color-Doppler ultrasound revealed occlusion of the external iliac vein and the left common femoral vein with no features of acute thrombosis. There were no signs of May-Thurner syndrome (the left iliac vein being compressed by the right iliac artery), which leads to iliofemoral thrombosis in about $20 \%$ to $40 \%$ of cases (FIGURE 1ABC). ${ }^{1}$ Thrombophilia screening (FV Leiden mutation, prothrombin $20210 \mathrm{~A}$ variant, protein C activity [105\%, norm 10\%-140\%], antithrombin activity [95\%, norm $70 \%-140 \%]$, free protein $S$ concentration [65\%, norm 59\%-118\%], anti- $\beta_{2}$-glycoprotein I [immunoglobulin (Ig) G 6.4 SGU, norm <15.7 and IgM 2.7 SMU, norm <14.0; 99 percentile] and anticardiolipin (ACL) antibodies [7.5 IgM phospholipids (MPL), norm <17.0; 99 percentile], lupus anticoagulant) showed heterozygosity for FV Leiden mutation (1691A/G) and slightly elevated IgG ACL antibodies (15.41 IgG phospholipids (GPL), norm $<10$ ). Based on the history, physical examination, and ancillary tests, the patient was diagnosed with CVI (class C3) with underlying proximal DVT and thrombophilia, given a 4-year history of DVT without thrombosis recurrence. She received enoxaparin $60 \mathrm{mg}$ subcutaneously daily (according to the patient's request) as long as possible (awaiting her consent to an oral anticoagulant [OA] for further treatment), compression therapy (class 2 compression stockings), and flavonoids.

A 9-month follow-up revealed collateral development involving the inferior epigastric vein and the left pubic vein, swelling of the entire lower extremity with the ankle circumference measuring $3 \mathrm{~cm}$ more than the right leg (3 points using 
the Wells score). Repeat ultrasound showed a solid and immobile occlusion filling the lumen of the common femoral vein and the left external iliac vein. The common iliac vein, the internal vein, and the inferior vena cava were free from blood clots. However, the inferior epigastric and pubic veins were dilated and provided collateral flow via suprapubic varicose veins to the $1.5 \mathrm{~cm}$ dilated right common femoral vein. There were only scattered foci of recanalization within the lumen-filling clot in the left common iliac vein (FIGURE 1DEF). The D-dimer level was $78 \mu \mathrm{g} / \mathrm{l}$ (norm 0-160 $\mu \mathrm{g} / \mathrm{l}$ ). Repeat thrombophilia testing showed persistently slightly elevated ACL IgG antibodies not allowing to diagnose antiphospolipid syndrome 18.5 IgG phospholipids (norm 0-13.1). The polymorphisms of the Val34Leu factor XIII (FXIII) (rs5985) and 312Ala FGA (rs6050) genes were determined by using the TaqMan SNP genotyping technique on an ABI PRISM 7900HT Fast Real-Time PCR System (Applied Biosystems)., ${ }^{2,3}$ Genotyping for the 2 genetic polymorphisms known to adversely affect fibrin clot structure and function showed that the patient was a heterozygous carrier of both minor alleles (FXIII Val34Leu and $\alpha$-chain fibrinogen 312Ala).

DISCUSSION Treatment options for acute DVT and pulmonary artery thrombosis include intravenous unfractionated heparin (UFH), low-molecular-weight heparin (LMWH) or fondaparinux, UFH or LMWH combined with an OA to achieve the target INR range of 2 to 3 . Chronic anticoagulation therapy in patients with a first episode of VTE secondary to transient risk factors should include OA for 3 months. In the case of idiopathic thrombosis, anticoagulation should be administered for at least 3 months and then decision on the duration of therapy should be taken individually depending on the risk-benefit ratio of OA. ${ }^{4}$ Residual venous thrombosis and D-dimer concentration may help in the assessment of individual indications. The DACUS study showed that residual venous thrombosis may indicate the need for prolonged OA. ${ }^{5}$ The PROLONG study ${ }^{6}$ revealed that patients with elevated D-dimer levels are at increased risk of recurrent VTE after discontinuation of anticoagulants. The results of these studies indicate the need for prolonged use of $\mathrm{OA}$ in patients with residual venous thrombosis or elevated D-dimer concentrations. For this reason, a decision to continue therapy may be made at the end of each treatment period based on the results of ultrasound examination (for the presence of residual thrombus) or elevated D-dimer concentrations.

In the present study, DVT could have been additionally precipitated by pregnancy, postabortion sequelae, and oral contraceptives like in our patient. The patient was found to have FV Leiden mutation suggesting that it might have been implicated in the development of proximal DVT. It is probably more difficult to explain the duration of the disease and no signs of recanalization.
The carriership of both FXIII Val34Leu and $\alpha$-chain fibrinogen 312Ala allelic variants, which were associated with an increased risk of VTE, ${ }^{2,3}$ could indicate that the formation of dense, less permeable fibrin clots composed of thin fibers, relatively resistant to lysis, might at least to some extent contribute to residual venous thrombosis. ${ }^{7}$ It might be speculated that the presence of both polymorphisms, unfavorably influencing fibrin clot properties, combined with FV Leiden and elevated ACL antibodies, increases the risk of persistently occluded veins despite standard therapy in a subgroup of VTE patients.

Unsuccessful conservative treatment in a young symptomatic patient should encourage a more aggressive approach. Recanalization of chronic occlusions by means of balloon angioplasty with stenting relieves leg edema and pain in most patients. However, it has been reported that primary stent patency at 3 years after placement is only about $60 \%$ in the case of nonneoplastic postthrombotic venous obstruction in the femoral and iliac vein or the vena cava inferior. ${ }^{8}$ For this reason, in our patient a decision on invasive treatment should be made with utmost caution.

We conclude that in some young patients with residual thrombosis in proximal deep veins, genetic polymorphisms known to adversely effect fibrin structure and lysis might contribute to suboptimal outcomes of anticoagulation. We believe that in individuals with complex thrombophilia and proximal DVT prolonged treatment should be administered. It might be speculated that FXIII Leu34 and $\alpha$-fibrinogen Ala312 alleles could be useful in the evaluation of young patients with idiopathic proximal thrombosis.

Acknowledgments We thank Professor Anetta Undas for invaluable help in the preparation of this manuscript.

\section{REFERENCES}

1 Delis KT, Bountouroglou D, Mansfield AO. Venous claudication in iliofemoral thrombosis: long-term effects on venous hemodynamics, clinical status, and quality of life. Ann Surg. 2004; 239: 118-126.

2 Balogh I, Szôke G, Kárpáti L, et al. Val34Leu polymorphism of plasma factor XIII: biochemistry and epidemiology in familial thrombophilia. Blood. 2000; 96: 2479-2486.

3 Carter AM, Catto AJ, Kohler HP, et al. Alpha fibrinogen Thr312Ala polymorphism and venous thromboembolism. Circulation. 2003; 107: 2326-2330.

4 [Prevention and treatment of venous thromboembolism: Polish Consensus 2008]. Acta Angiologica. 2008; 13 (Suppl C): C1-C22. Polish.

5 Siragusa S, Malato A, Anastasio R, et al. Residual vein thrombosis to establish duration of anticoagulation after a first episode of deep vein thrombosis: the Duration of Anticoagulation based on Compression UltraSonography (DACUS) study. Blood. 2008; 112: 511-515.

6 Palareti G, Cosmi B, Legnani C, et al. PROLONG Investigators. D-dimer testing to determine the duration of anticoagulation therapy. N Engl J Med. 2006; 355: 1780-1789.

7 Scott EM, Ariëns RAS, Grant PJ. Genetic and environmental determinants of fibrin structure and function. Relevance to clinical disease. Arterioscler Thromb Vasc Biol. 2004; 24: 1558-1566.

8 Negelen $\mathrm{P}$, Hollis K, Olivier $\mathrm{J}$, et al. Stenting of the venous outflow in chronic venous disease: long term stent-related outcome, clinical and hemodynamic results. J Vasc Surg. 2007; 46: 979-990. 


\title{
Rezydualna zakrzepica biodrowo-udowa u 31-letniej kobiety stosującej doustne środki antykoncepcyjne $z$ heterozygotyczną postacią czynnika V Leiden, allelem Val34Leu czynnika XIII i allelem Thr312Ala $\alpha$-fibrynogenu
}

\author{
Mariola Cieśla-Dul1,2, Bogusław Gawęda ${ }^{1,2}$, Ewa Wypasek², Maria Różańska³ , Jerzy Sadowski1,2 \\ 1 Klinika Chirurgii Serca, Naczyń i Transplantologii, Instytut Kardiologii, Uniwersytet Jagielloński, Collegium Medicum, Kraków \\ 2 Krakowski Szpital Specjalistyczny im. Jana Pawła II, Kraków \\ 35 Wojskowy Szpital Kliniczny z Polikliniką, Kraków
}

\section{SŁOWA KLUCZOWE}

fibryna, trombofilia, zakrzepica biodrowo-udowa
Adres do korespondencji: dr med. Mariola Cieśla-Dul, Klinika Chirurgii Serca, Naczyń i Transplantologii, Instytut Kardiologii, Uniwersytet Jagielloński, Collegium Medicum, ul. Prądnicka 80, 31-022 Kraków, tel.: 012-614-30-75, fax: 012-423-39-00, e-mail: mdul@szpitaljp2.krakow.pl Praca wpłynęta: 13.09.2009. Przyjęta do druku: 20.11.2009. Nie zgłoszono sprzeczności interesów.

Pol Arch Med Wewn. 2009; 119 (12): 822-825

Copyright by Medycyna Praktyczna, Kraków 2009

\section{STRESZCZENIE}

Przedstawiono przypadek 31-letniej pacjentki stosującej doustne środki antykoncepcyjne, u której 3 lata wcześniej rozpoznano zakrzepicę biodrowo-udową nie wykazującą tendencji do rekanalizacji mimo zadawalającego leczenia przeciwkrzepliwego i nieobecności chorób wspótistniejących. W badaniu trombofilii stwierdzono mutacje genu czynnika V Leiden w postaci heterozygotycznej. Ponadto wykryto obecność allelu Leu34 czynnika XIII i Ala312 łańcucha a-fibrynogenu w postaci heterozygotycznej, o których wiadomo, że niekorzystnie wpływają na strukturę i tempo lizy skrzepu fibrynowego. Można przypuszczać, że u przedstawionej pacjentki wspótistnienie 3 polimorfizmów mogło przyczynić się do zakrzepicy proksymalnej nie poddającej się leczeniu. Uważamy, że u niektórych młodych pacjentów z zakrzepicą żył głębokich warto rozważyć wykonanie również oznaczeń w kierunku polimorfizmów czynnika XIII i a-fibrynogenu. 